\title{
Visual and refractive outcome of lens extraction or cataract surgery combined with limbal relaxing insicion in keratoconic eyes
}

\section{Keratokonuslu gözlerde limbal gevşetici insizyon ile birlikte yapılan lens değişimi veya katarakt cerrahisinin görsel ve refraktif sonuçları}

\author{
Hanefi ÇAKIR ${ }^{1}$, Mehmet TETiKoĞLU², Medine Aslı YILDIRIM³ ${ }^{3}$, Feyza ALTIN³ ${ }^{3}$ Uğur ÇELík
}

\section{ABSTRACT}

To evaluate the refractive and visual outcome of lens extraction or cataract surgery combined with limbal relaxing insicion in keratoconic eyes. This study included 18 keratoconic eyes of 12 patients who underwent lens extraction or cataract surgery combined with limbal relaxing insicion. Changes in the uncorrected distance visual acuity (UDVA), corrected distance visual acuity (CDVA), spherical equivalent (SE), and cylindrical error were assessed. The preoperative mean SE was $-8.87 \pm 6.97$ diopters (D) and this number improved to $-2.27 \pm 1.48 \mathrm{D}$ at the last visit. The refractive astigmatisms were significantly reduced from $-4.65 \pm 1.68$ $D$ to $-2.40 \pm 1.8 D(p<0.001)$. The mean surgically induced astigmatism, calculated by a vector analysis, was $1.93 \pm 1.57 \mathrm{D}$. The mean preoperative steepest meridian keratometry reading (K1) value was $52.97 \pm 5.1 \mathrm{D}$, which decreased to $50.96 \pm 4.5 \mathrm{D}$ at the last visit $(p<0.001)$. The mean logMAR CDVA improved from $0.71 \pm 0.39$ to $0.24 \pm 0.18$ ( $p<0.001)$. The CDVA was achieved with spectacles, and no patients needed to return to rigid contact lenses. Limbal relaxing insicion combined with lens extraction or cataract surgery can be used effectively to decrease irregular astigmatism. This technique improves corrected and uncorrected visual acuity by decreasing both spherical and cylindrical error in keratoconic eyes, and thus reduces dependency on contact lenses.

Key words: Keratoconus, irregular astigmatism, limbal relaxing insicion, cataract surgery
Öz

Bu çalışmada, keratokonuslu gözlerde arkuat keratotomi ile birlikte yapılan katarakt cerrahsinin görsel ve refraktif sonuçları değerlendirilmiştir. Çalışmaya arkuat keratotomi ile kombine katarakt cerrahisi uygulanan 12 keratokonus hastsının 18 keratokonuslu gözü dâhil edildi. Düzeltilmemiş uzak görme keskinliği (UDVA), düzeltilmiş uzak görme keskinliği (CDVA), sferik eşdeğer (SE) ve silindirik değer değişiklikleri değerlendirildi. Preoperatif $S E-8,87 \pm 6,97$ dioptri (D) iken ve son muayene SE değeri $-2,27 \pm 1.48 \mathrm{D}$ idi. Refraktif astigmatizma değeri $-4,65 \pm 1,68 \mathrm{D}$ iken, $-2,40 \pm 1,8 D^{\prime}$ ye anlamlı derecede azaldı $(p<0.001)$. Vektör analizi ile hesaplanan cerrahiye bağlı astigmatizma değeri ortalaması $1.93 \pm 1.57 D$ idi. Ortalama logMAR CDVA değeri 0.71 \pm 0.39 'dan $0.24 \pm 0.18^{\prime}$ ye yükselmiş idi ( $\left.p<0.001\right)$. CDVA değerleri gözlük ile elde edilmiş olup, hiçbir hastada sert kontakt lenslere gereksinim duyulmadı. Sonuç olarak, katarakt cerrahisi ile kombine yapılabilen arkuat keratotomi düzensiz astigmatizmayı azaltmak için etkili bir şekilde kullanılabileceği görülmüştür. Bu teknik düzeltilmiş ve düzeltilmemiş görme keskinliğini keratokonuslu gözlerde sferik ve silindirik hataları azaltarak kontakt lens bağımlılı̆ını azaltmaktadır.

Anahtar kelimeler: Keratoconus, irregüler astigmatizm, arkuat keratotomi, katarakt cerrahisi

\section{INTRODUCTION}

Keratoconus is a progressive noninflammatory dise- ase, which is characterized by localized thinning and steepening and leads to protrusion of the cornea. This disease progression results in irregular astigma-

The study was presented at the American Society of Cataract and Refractive Surgery (ASCRS) Annual Meeting that took place on April 17-22, 2015, in San- Diego, USA.

Received: 12.11 .2015

Accepted: 22.11.2015

${ }^{1}$ Turkey Hospital Eye Clinic, Istanbul, Turkey

${ }^{2}$ Dumlupinar University School of Medicine, Department of Ophthalmology

${ }^{3}$ Okmeydani Training and Research Hospital, Department of Ophthalmology

${ }^{4}$ Istanbul Medeniyet University Medical Faculty, Department of Ophthalmology

Yazışma adresi: Yrd. Doç. Dr. Ugur Celik, Medeniyet Üniversitesi Tıp Fakültesi Göztepe Eğitim ve Araştırma Hastanesi Göz Hastalıkları Servisi, Doktor Erkin Caddesi, 34722-Kadıköy-i̇stanbul

e-mail: h.ugurcelik@gmail.com 
tism and myopia of variable severity, thus affecting visual quality. The onset and progression of the disease starts during the second decade of life and stabilizes in the third or fourth decade ${ }^{1,2}$.

The probability of cataract formation increases with age, and cataract surgery may eventually be necessary. Phacoemulsification in these patients remedies the visually significant cataract and corrects large spherical errors to improve their visual acuity. Performing cataract surgery in patients with keratoconus is very challenging due to the difficulty in calculating the intraocular lens (IOL) power ${ }^{3,4}$.

Astigmatism induces image distortion; thus, surgically correcting the astigmatism results in a better postoperative uncorrected distance visual acuity ${ }^{5,6}$. Preexisting astigmatism can be corrected during cataract surgery by several techniques. Limbal relaxing incisions are easy to perform, but have limited precision? ${ }^{7}$. Toric IOL implantation is another common astigmatic correction technique, but the calculations are difficult, particularly in patients with keratoconus ${ }^{2,8}$. Limbal relaxing incision is a related method that induces the cornea to correct its topography through its natural healing processes, which finally reduces the astigmatism. To the best of our knowledge, there is limited research on the topic of lens extraction or cataract surgery combined with limbal relaxing incision in patients with keratoconus ${ }^{9-11}$. The purpose of this study was to determine the refractive and visual outcome of lens extraction or cataract surgery combined with limbal relaxing incision in keratoconic eyes.

\section{MATERIAL and METHODS}

This retrospective review of combined lens extraction or cataract surgery and limbal relaxing incision by a single surgeon $(\mathrm{HC})$ included 18 eyes of 12 patients with keratoconus who had minimal lens opacity (LOCS III NO 1-2, C 1-2, P 1-2) ${ }^{12}$ or high myopic refraction with a clear lens. The inclusion criteria were as follows: Age greater than 40 years, contact lens intolerance, refractive stability for at least 2 years, a minimum follow-up of 6 months, and astigmatism greater than 3 diopters (D). The exclusion criteria were visual dysfunctions resulting from other diseases such as diabetic retinopathy, glaucoma, or corneal scarring. Informed consent was obtained from all patients before the surgery.

The principles of the study were compliant to the declaration of Helsinki and approved by the local ethics committee.

Patients were diagnosed as stable keratoconus based on clinical examinations, which included slit lamp findings such as corneal thinning or protrusion, and corneal topography measurements using Orbscan II (Bausch \& Lomb, Rochester, NY, USA). We classified the severity of the keratoconus as mild, moderate, or severe based on the average keratometry (K) readings and the classification of Krumeich et al. ${ }^{13}$ Mild keratoconus was defined as an average $\mathrm{K}$ reading of less than or equal to $48 \mathrm{D}$, moderate keratoconus as an average $K$ reading more than $48 \mathrm{D}$ but less than or equal to $55 \mathrm{D}$, and severe keratoconus as an average $\mathrm{K}$ reading more than $55 \mathrm{D}$.

Biometry was performed with partial coherence laser interferometry (IOL Master; Carl Zeiss Meditec, Jena, Germany), and in some cases, an ultrasound $A$ scan biometer (Tomey AL-100) was used when the IOL Master failed. The SRK II formula was used to calculate the IOL power, and the K-values obtained with the Orbscan II were used for the calculation of IOL. Actual $\mathrm{K}$ values were used for the mild and moderate keratoconus; but an average of the actual and standard K (43.25 D) values was used for the calculation of IOL power in severe keratoconus. A complete ophthalmic examination was performed preoperatively and postoperatively, which included the uncorrected distance visual acuity (UDVA), corrected distance visual acuity (CDVA), spherical equivalent (SE), cylindrical error, corneal ultrasound pachymetry, and $\mathrm{K}$ readings. A slit-lamp microscopic examination of the anterior segment, fundus, and applanation tonometry was also performed before surgery.

An uneventful phacoemulsification with IOL in-the- 
bag implantation was accomplished through a 2.8 $\mathrm{mm}$ limbal incision at the steepest meridian under topical anesthesia. For the limbal relaxing incision, we modified the Thornton nomogram for astigmatic keratotomy, ${ }^{14}$ which was performed at the steep vertical axis of the cornea 180 degrees opposite to the phacoemulsification incision and near the limbus. At the first visit, the patient was operated on for an IOL exchange if the refractive error was greater than 3 D. All statistical analyses were performed with the Statistical Package of Social Sciences (SPSS), version $^{21}$. The distribution of data was determined by Kolmogorov-Smirnov tests, and paired-sample t tests were used to compare repeated measurements. A p-value of less than 0.05 was considered significant. The CDVA and UDVA were converted to the logarithm of the minimum angle of resolution (logMAR). Surgically induced astigmatism (SIA) was evaluated by a vector analysis ${ }^{15}$.

\section{RESULTS}

Eighteen eyes of twelve patients with keratoconus, who underwent lens extraction or cataract surgery with limbal relaxing incision were included in this study. The mean patient age was $51.94 \pm 8.24$ years (range, $40-67$ years), and $81.3 \%$ of the patients were female. The mean follow-up was $10.59 \pm 2.17$ months (7-16 months). Table 1 shows the characteristics of the patients. An uneventful surgery with an IOL inthe-bag implantation was performed in all cases. An IOL exchange was necessary in three eyes (16.6\%), and a second operation was performed successfully on both eyes. One patient declined the second operation with the aim to exchange the IOL.

The preoperative mean SE was $-8.87 \pm 6.97 \mathrm{D}$ (range

Table 1. Characteristics of kerataconus patients.

\begin{tabular}{lc}
\hline Severity of keratoconus & \\
\hline Mild $<48$ & $4 / 18$ eyes \\
Moderate $48-55$ & $8 / 18$ eyes \\
Sever $\geq 55 D$ & $6 / 18$ eyes \\
Axial length & $24,68 \pm 2,3 \mathrm{~mm}$ (range $21,50-29,8)$ \\
Pachymetry & $457 \pm 58,9 \mu$ (range $330-568)$ \\
\hline
\end{tabular}

-25.00 to -1.00 ), and it improved to $-2.27 \pm 1.48 \mathrm{D}$ (range -5.50 to -0.50$)$ at the last visit $(p=0.0001)$ (Figure 1 ). The preoperative mean refractive astigmatism was $-4.65 \pm 1.68 \mathrm{D}$ (range -10.00 to -3.00 ), and improved to $-2.40 \pm 1.84 \mathrm{D}$ (range -6.75 to -0.75 ) at the last visit ( $p=0.0001)$. The mean SIA, calculated by a vector analysis, was $1.93 \pm 1.57 \mathrm{D}$ (range 0.00 to 4.90 ).

The mean keratometric astigmatism was $-4.87 \pm 1.9$ $D$ (range -9.10 to -2.1 ) before the operations, and the postoperative mean was $-3.00 \pm 1.7 \mathrm{D}$ (range -7.40 to -0.75 ). The preoperative mean $\mathrm{K} 1$ value was $52.97 \pm 5.1 \mathrm{D}$ (range 46.8 to 65.00 ) and the mean $\mathrm{K} 2$

Table 2. Preoperative and postoperative values of patients.

\begin{tabular}{lccc}
\hline & Preoperative & Postoperative & p value \\
\hline Spheric Value & $-6,81 \pm 6,37$ & $-0,65 \pm 1,16$ & $=0.0001$ \\
Cylinder Value & $-4,65 \pm 1,68$ & $-2,40 \pm 1,84$ & $=0.0001$ \\
K1 Value & $52,95 \pm 5,11$ & $50,96 \pm 4,53$ & $=0.0001$ \\
K2 Value & $48,09 \pm 4,65$ & $47,87 \pm 4,73$ & $=0.0001$ \\
UCVA & $0,08 \pm 0,05$ & $0,41 \pm 0,20$ & $=0.0001$ \\
CDVA & $0,25 \pm 0,15$ & $0,60 \pm 0,22$ & $=0.0001$
\end{tabular}

UCVA: Uncorrected visual acuity, CDVA: Corrected Distance Visual Acuity

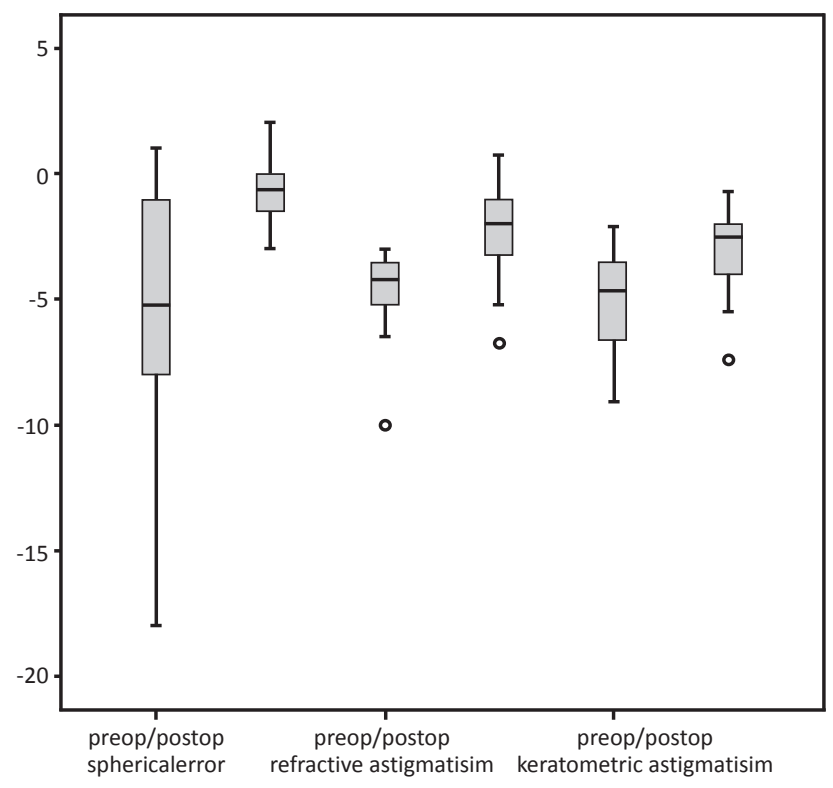

Figure 1. Preoperative and postoperative refractive values. 
value was $48.09 \pm 4.6 \mathrm{D}$ (range 40.3 to 56.1 ). The postoperative mean $\mathrm{K} 1$ value was $50.96 \pm 4.5 \mathrm{D}$ (range 44.5 to 61.0 ) and the mean $K 2$ value was $47.87 \pm 4.7$ $D$ (range 40.3 to 58.1). The change in the mean K1 value was statistically significant $(p=0.0001)$, but there was no statistically significant difference between the mean $K 2$ values ( $p=0.544)$.

Preoperatively, the mean UDVA was $1.1 \pm 0.46$ (range 1.30 to 0.70 ) logMAR and the mean CDVA was $0.71 \pm 0.39$ (range 1.0 to 0.22 ) logMAR. At the last visit, the mean UDVA was $0.43 \pm 0.23$ (range 1.0 to 0.15 ) $\log M A R$ and the mean CDVA was $0.24 \pm 0.18$ ( 0.70 to $0.00) \log M A R$. These differences were statistically significant $(p=0.0001)$. None of the patients developed any complications. Table 2 shows the summary of preoperative and postoperative values of the patients.

\section{DISCUSSION}

After stabilization of keratoconus later in life, the major causes of poor visual acuity and quality are cataract formation, high myopia, and irregular astigmatism. There are several corneal surgical procedures to correct refractive error, such as photorefractive keratectomy and laser-assisted in situ keratomileusis, but a higher risk of ectasia has been reported for keratoconus following the use of these surgical techniques ${ }^{16,17}$. Intracorneal ring segments have a limitation for the correction of the high spherical equivalent ${ }^{18}$. Corneal transplants routinely provide good vision, but the healing time is slow, and visual recovery may require monthly follow-up. A refractive lens exchange with a toric or phakic IOL implantation are the other choices for this purpose ${ }^{19,20}$. Another choice is phacoemulsification for both the cataracts and large spherical errors for patients in the presbyopic age range with keratoconus ${ }^{3,4,9}$.

Lens extraction or cataract surgery in patients with keratoconus is challenging because of the difficulty in obtaining accurate and consistent keratometry readings due to several reasons. The visual axis of keratoconic eyes may not pass through the steepest portion of the cornea because of the displacement of the apex of the cone. In addition, the anterior chamber depth in keratoconus is deeper than normal eyes, which affects the position of the IOL. Furthermore, the corneal irregularity and tear film reflex may make it difficult to obtain repeatable $\mathrm{K}$ values ${ }^{9,21,22}$.

Published literature to guide the IOL power selection in the presence of keratoconus is limited. Thebpatiphat et al. ${ }^{3}$ compared the SRK, SRK II, and SRKT formulas and found that in keratoconus patients, the most accurate IOL power was achieved with the SRK II formula, although the accuracy of biometry was worse in eyes with advanced keratoconus. Leccisotti reported a $26 \%$ intraoperative (using autorefractometry during surgery) and 6\% postoperative IOL exchange due to inaccurate calculation of the IOL power by the Holladay 2 formula ${ }^{4}$. Watson et al. ${ }^{9}$ reported on the outcome of cataract surgery in eyes with keratoconus that used the SRK $\mathrm{T}$ formula and actual $\mathrm{K}$ values for the IOL power calculation. They found that using the actual $\mathrm{K}$ values is a suitable option for eyes with a mean $\mathrm{K}$ of less than or equal $55 \mathrm{D}$. In severe keratoconus, they reported a large hyperopic error when using the actual $\mathrm{K}$ values and concluded that the standard $K$ value should be used in these eyes. In our study using the SRK II formula, an IOL exchange was necessary in three eyes (16.6\%), two of which had severe keratoconus. In mild and moderate keratoconus, using the actual $\mathrm{K}$ values with the SRK II formula was very successful, but in severe keratoconus, using the average of the actual and standard $\mathrm{K}$ values with the SRK II formula was not as successful as expected.

Leccisotti et al. ${ }^{4}$ who performed refractive lens exchange (RLE) in a series of 34 eyes with stage I or II keratoconus, reported that the SE decreased from $-11.0 \mathrm{D}$ to a postoperative mean of $-1.31 \mathrm{D}$, and the preoperative mean refractive cylinder decreased from $1.86 \mathrm{D}$ to $1.22 \mathrm{D}$ postoperatively, with a mean SIA of $0.54 \mathrm{D}$. In another study of RLE with toric IOL implantation, the mean preoperative refractive cylinder was $3.95 \mathrm{D}$, which decreased to $1.36 \mathrm{D}$ postoperatively, while the SE decreased from $-7.10 \mathrm{D}$ to -0.46 
D10. Rowsey et al. ${ }^{11}$ assessed seventeen eyes with keratoconus that had toric IOL implantations, six of which received a limited astigmatic keratotomy. The mean refractive cylinder declined from $-3.15 \mathrm{D}$ to $-0.94 \mathrm{D}$, and the mean keratometric cylinder decreased from $4.16 \mathrm{D}$ to $3.5 \mathrm{D}$.

We combined limbal relaxing incision with lens extraction or cataract surgery that resulted in a decrease in the refractive cylinder by $2.25 \mathrm{D}$ and the keratometric cylinder by $1.87 \mathrm{D}$, with a mean SIA of 1.93 $\mathrm{D}$ and an SE reduction from -8.87 D to $-2.27 \mathrm{D}$. In this case series, alteration in the SE was similar to that of the other reports, but the astigmatic change was similar to that of toric IOL implantations and better than that of RLEs with IOL implantation. The lens extraction or cataract surgery predictably corrected the spherical errors in the keratoconic eyes, and a significant reduction in the cylindrical error can be achieved by limbal relaxing incision, an intervention in the cornea that is responsible for the pathology of keratoconus. Despite performing the same limbal relaxing incision in the patients with keratoconus, the SIA varied widely from 0.00 to $4.90 \mathrm{D}$, which we believe was due to the varied biomechanical properties of the keratoconic corneas. In our practice, we generally prefer to combine lens extraction or cataract surgery with limbal relaxing incision in patients with keratoconus. Although a toric $\mathrm{IOL}$ is a good option in keratoconic eyes, there are some paradoxes about their use. First, estimating the IOL power and its location is more difficult. Second, a major problem in keratoconus is the irregular corneal astigmatism, and a toric IOL implantation has no effect on the cornea. Third, if patients need a rigid contact lens after a toric IOL insertion or keratoplasty, the last refraction cannot be predicted, and the toric IOL may need to be exchanged ${ }^{9}$.

There were improvements in the UDVA and CDVA in most studies about cataract surgery on keratoconic eyes ${ }^{3,4,19}$. The uncorrected cylinder and irregular astigmatism will degrade the visual image, and the CDVA would still be reduced. Therefore, patients may also wish to return to rigid contact lenses after the cataract surgery. In our study; we performed the limbal relaxing incision to the peripheral cornea due to the paracentral corneal thinning associated with keratoconus. Our aim was not to correct the astigmatism, but to degrade it to a tolerable level by combining the lens extraction or cataract surgery with limbal relaxing incision. The mean CDVA improved from 0.71 to 0.24 . The CDVA was achieved with spectacles, and no patients needed to return to rigid contact lenses. We believe this is the result of the limbal relaxing incision.

In summary, the findings of this study showed that lens extraction or cataract surgery with limbal relaxing incision yielded a significant improvement in the corrected and uncorrected visual acuity and a decrease in the keratometry values, without apparent complications in the keratoconic eyes. Based on these findings, it can be extrapolated that lens extraction or cataract surgery with limbal relaxing incision may be a good option to correct irregular astigmatism in keratoconic eyes.

\section{REFERENCES}

1. Rabinowitz YS. Keratoconus. Surv Ophthalmol 1998;42:297-319. http://dx.doi.org/10.1016/S0039-6257(97)00119-7

2. Krachmer JH, Feder RS, Belin MW. Keratoconus and related noninflammatory corneal thinning disorders. Surv Ophthalmol 1984;28:293-322. http://dx.doi.org/10.1016/0039-6257(84)90094-8

3. Thebpatiphat N, Hammersmith KM, Rapuano CJ, et al. Cataract surgery in keratoconus. Eye Contact Lens 2007;33(5):244-6. http://dx.doi.org/10.1097/ICL.0b013e318030c96d

4. Leccisotti A. Refractive lens exchange in keratoconus. J Cataract Refractive Surg 2006;32(5):742-6. http://dx.doi.org/10.1016/j.jcrs.2006.01.063

5. Guyton DL. Prescribing cylinders: the problem of distortion. Surv Ophthalmol 1977;22(3):177-188. http://dx.doi.org/10.1016/0039-6257(77)90054-6

6. Watanaba K, Negishi K, Doğru M, et al. Effect of pupil size on un corrected visual acuity in pseudophakic eyes with astigmatism. J Refract Surg 2013;29(1):25-9. http://dx.doi.org/10.3928/1081597X-20121106-03

7. Found S, Kamiya K, Aizawa D, et al. Limbal relaxing incision during cataract extraction versus photoastigmatic keratectomy after cataract extraction in controlling pre-existing corneal astigmatism. Graefes Arch Clin Exp Ophthalmol 2010;248(7):1029-35. http://dx.doi.org/10.1007/s00417-009-1272-6

8. Holland E, Lane S, Horn JD, et al. The AcrySof Toric intraocular lens in subjects with cataracts and corneal astigmatism: a randomized, subject-masked, parallel-group, 1-year study. 
Ophthalmology 2010;117(11):2104-2111. http://dx.doi.org/10.1016/j.ophtha.2010.07.033

9. Watson MP, Anand $S$, Bhogal $M$, et al. Cataract surgery outcome in eyes with keratoconus. $\mathrm{Br} J$ Ophthalmol 2013;98(3):361-4. http://dx.doi.org/10.1136/bjophthalmol-2013-303829

10. Jaimes $M$, Xacur-Garcia F, Alvarez-Malloni D, et al. Refractive lens Exchange with toric intraocular lenses in keratoconus. $J$ Refract Surg 2011;27(9):658-64. http://dx.doi.org/10.3928/1081597X-20110531-01

11. Rowsey JJ, Gills JP, Gills III P. Treating keratoconus with astigmatic keratotomy and intraocular lenses: a new approach. Int Ophthalmol Clin 2003 Summer;43(3):81-92. http://dx.doi.org/10.1097/00004397-200343030-00008

12. Chylack LT Jr, Wolfe JK, Singer DM, et al. The Lens Opacities Classification System III. The Longitudinal Study of Cataract Study Group. Arch Ophthalmol 1993;111(6):831-6. http://dx.doi.org/10.1001/archopht.1993.01090060119035

13. Krumeich JH, Daniel J, Knulle A. Live-epikeratophakia for keratoconus. J Cataract Refract Surg 1998;24:456-463. http://dx.doi.org/10.1016/S0886-3350(98)80284-8

14. Thornton SP. Thornton guide for radial keratotomy incisions and optical zone size. Journal of Refractive Surgery 1985;1:29-33. http://dx.doi.org/10.3928/1081-597X-19850301-08

15. Holladay JT, Cravy TV, Koch DD. Calculating the surgically induced refractive change following ocular surgery. J Cataract Refractive Surg 1992;18(5):429-43. http://dx.doi.org/10.1016/S0886-3350(13)80095-8
16. Chiang RK, Park AJ, Rapuano CJ, et al. Bilateral keratoconus after LASIK in a keratoconus patient. Eye Contact Lens 2003;29(2):90-2. http://dx.doi.org/10.1097/01.ICL.0000060780.24132.51

17. Kremer I, Shochot Y, Kaplan A, et al. Three year results of photoastigmatic refractive keratectomy for mild and atypical keratoconus. J Cataract Refractive Surg 1998;24(12):1581-8. http://dx.doi.org/10.1016/S0886-3350(98)80346-5

18. Alió JL, Shabayek MH, Belda JI, et al. Analysis of result related to good and bad outcomes of results related to good and bad outcomes of intacs implantation for keratoconus correction. $J$ Cataract Refractive Surg 2006;32(5):756-61. http://dx.doi.org/10.1016/j.jcrs.2006.02.012

19. Nanavaty MA, Lake DB, Daya SM. Outcomes of pseudophakic toric intraocular lens implantation in Keratoconic eyes with cataract. J Refract Surg 2012;28(12):884-9. http://dx.doi.org/10.3928/1081597X-20121106-02

20. Sedaghat $M$, Ansari-Astaneh $M R$, Zarei-Ghanavati $M$, et al. Artisan iris-supported phakic IOL implantation in patients with keratoconus: a review of 16 eyes. J Refract Surg 2011;27(7):489-93. http://dx.doi.org/10.3928/1081597X-20110203-01

21. Tomidokoro A, Oshika T, Amano S, et al. Changes in anterior and posterior corneal curvatures in keratoconus. Ophthalmology 2000;107:1328-32. http://dx.doi.org/10.1016/S0161-6420(00)00159-7

22. Kovacs I, Mihaltz K, Nemeth J, et al. Anterior chamber characteristics of keratoconus assessed by rotating Scheimpfl ug imaging. J Cataract Refract Surg 2010;36:1101-6. http://dx.doi.org/10.1016/j.jcrs.2009.12.046 